\title{
Productive Performance of Wheat Based on Nitrogen Fertilization in Coverage
}

\author{
Michael Jonathan Fernandes Alves ${ }^{1 *}$, Wilson Wagner Ribeiro Teixeira ${ }^{2}$, Edelclaiton Daros ${ }^{1}$, \\ Luís César Cassol ${ }^{3}$, João Augusto Lopes Pascoalino², Milton Ferreira de Moraes ${ }^{2}$ \\ ${ }^{1}$ Department of Plant Science and Crop Protection, Federal University of Parana, Curitiba, Brazil \\ ${ }^{2}$ Department of Soil Science, Federal University of Paraná, Curitiba, Brazil \\ ${ }^{3}$ University of Paraná Federal Technology, Pato Branco, Brazil \\ Email: ${ }^{*}$ michaelagronomia@gmail.com
}

Received 15 May 2015; accepted 26 June 2015; published 29 June 2015

Copyright (C) 2015 by authors and Scientific Research Publishing Inc.

This work is licensed under the Creative Commons Attribution International License (CC BY).

http://creativecommons.org/licenses/by/4.0/

(c) (i) Open Access

\begin{abstract}
The objective of this work was to evaluate genotypes of wheat depending on doses of $\mathrm{N}$ in order to determine the best value of $\mathrm{N}$ and the components of productivity of wheat. Experiment was carried out in Pato Branco-PR in soil classified as Eutrophic typical RED LATOSOL. The experimental design was randomized blocks, in $3 \times 5$ ( $\times \mathrm{N}$ doses genotypes), with three repetitions. The genotypes were: CD 108, CD 115 and BRS 220, and the doses of $n$ were: zero; 20; 40; 80 and $120 \mathrm{~kg}$ of $\mathbf{N} \cdot \mathrm{ha}^{-1}$, applied at the beginning of tillering. After harvest assessed number of Spike (NE), Tang (EC) length, grains per Spike (GE), mass of thousand grains (MMG), grain yield (R) and weight/HL (PH), application of $\mathrm{N}$ increased the NE and $\mathrm{R}$, and however decreased to MMG. The genotypes differed among themselves, featuring better performance of the NE (the BRS 220), CE (the CD 115) and R (the CD 108). There were positive correlations between the doses of $N$ with the $N E$ and $R$ and between $\mathrm{NE}$ with the $\mathrm{R}$, and negative correlation between doses of $\mathrm{N}$ with the MMG. It is concluded that the $\mathrm{NE}$ is the main factor that affects the $\mathrm{R}$ with $\mathrm{N}$ supply.
\end{abstract}

\section{Keywords}

Triticum aestivum, Grain Yield, Nitrogen

\section{Introduction}

Wheat (Triticum aestivum L.) is among the most cereals produced and consumed in the world, being grown in 218 million hectares and with production of about 713 million tons [1]. Nationally, the Paraná accounts for a

"Corresponding author.

How to cite this paper: Alves, M.J.F., Teixeira, W.W.R., Daros, E., Cassol, L.C., Pascoalino, J.A.L. and de Moraes, M.F. (2015) Productive Performance of Wheat Based on Nitrogen Fertilization in Coverage. American Journal of Plant Sciences, 6, 15871593. http://dx.doi.org/10.4236/ajps.2015.69159 
large part of the domestic production of wheat, representing a cultivated area of about 782 thousand hectares and the production of 2.1 tonnes, which means $41 \%$ of the national cultivated area and $48 \%$ of the total produced in Brazil [2].

The importance of this cereal in food and nutritional security [3] allies to the growing demand for food, which according to [4] no need to duplicate the world agricultural production, causes the recurrence of research to improve the productive potential of cultivated plants, using artifices like: genetic improvement and adoption of practices and/or cultivation management techniques.

Among the practices, the adequate supply of nutrients by fertilizing is inserted between the greater relevance in the expression of the productive potential of culture, in particular the supply of nitrogen $(\mathrm{N})$. In this context, over time several studies with nitrogen fertilization have been reported in the literature [5]-[10] who observed increases in the yield of wheat on the basis of the application of paragraph; on the other hand, [11]-[13] did not observe effects of $\mathrm{N}$ on wheat yield. The compiled results demonstrate no correlation between them, although most of the results show that the application of paragraph is beneficial [14].

However, when it comes to nitrogen fertilization combination instability and consequently their permanence in the productive system, causing what is called a variation of response, all the factors, such as: climate, soil, cultural management, application technology, dose and source of the fertilizer, which somehow influence in its dynamics must be considered that the $\mathrm{N}$ is one of the most expensive nutrients provided for crops in General, representing significant cost in production [15].

At the same time the environments and genotypes also wield great influence, whether on nutrient dynamics and efficiency of utilization and response to nutrient applied respectively. Thus, the objective of this work was to evaluate genotypes of wheat based on $\mathrm{N}$ topdressing doses.

\section{Material and Methods}

The experiment was conducted in the experimental area of Federal Technological University of Paraná, in Pato Branco-PR ( $26^{\circ} 41^{\prime} \mathrm{S}$ and $56^{\circ} 07^{\prime} \mathrm{E}$ altitude of $716 \mathrm{~m}$ ) in the period from July to September 2009. The climate of the region, according to Koppen classification is humid subtropical mesothermic (Cfb), with average temperatures of $20.4^{\circ} \mathrm{C}$ in summer and $12.7^{\circ} \mathrm{C}$ in winter [16]. The average rainfall is between 1400 to $1600 \mathrm{~mm} \cdot \mathrm{year}^{-1}$, with occurrences of frost and hail. The pluvial precipitation data and temperatures for the period of conducting of experiment were obtained Simepar meteorological station in Pato Branco-PR (Figure 1).

The installation location of the experiment consisted of a RED LATOSOL typical Eutrophic [17], whose chemical characteristics of layer $0-0.20 \mathrm{~m}$ were: $\mathrm{pH}\left(\mathrm{CaCl}_{2} 0.01 \mathrm{~mol} \cdot \mathrm{L}^{-1}\right)=5.20 ; \mathrm{M} . \mathrm{O}=56.29 \mathrm{~g} \cdot \mathrm{dm}^{-3} ; \mathrm{P}$ (Mehlich-1) = $5.89 \mathrm{mg} \cdot \mathrm{dm}^{-3} ; \mathrm{K}=0.30 \mathrm{cmol}_{\mathrm{c}} \cdot \mathrm{dm}^{-3} ; \mathrm{Ca}=5.52 \mathrm{cmol}_{\mathrm{c}} \cdot \mathrm{dm}^{-3} ; \mathrm{Mg}=3.19 \mathrm{cmol}_{\mathrm{c}} \cdot \mathrm{dm}^{-3} ; \mathrm{H}+\mathrm{Al}=4.20$ $\mathrm{cmol}_{\mathrm{c}} \cdot \mathrm{dm}^{-3}$, which means a $68.21 \%$ base saturation. The area used for deployment of the experiment was representative of the region, whose history was based on the cultivation of soybean (summer) and wheat (winter).

Before the sowing of wheat, the area was dried out with the herbicide glyphosate $\left(1.44 \mathrm{~kg} \cdot \mathrm{ha}^{-1}\right.$ of a.i.). The genotypes were sown mechanically, obtaining a density of 350 seeds suitable $\cdot \mathrm{m}^{-2}$. The plots were composed of six lines of $5.0 \mathrm{~m}$ long, spaced $0.20 \mathrm{~m}$; considered as useful area the four central rows. Control of weeds, pests and diseases were carried out in accordance with the technical recommendations of the culture [18].

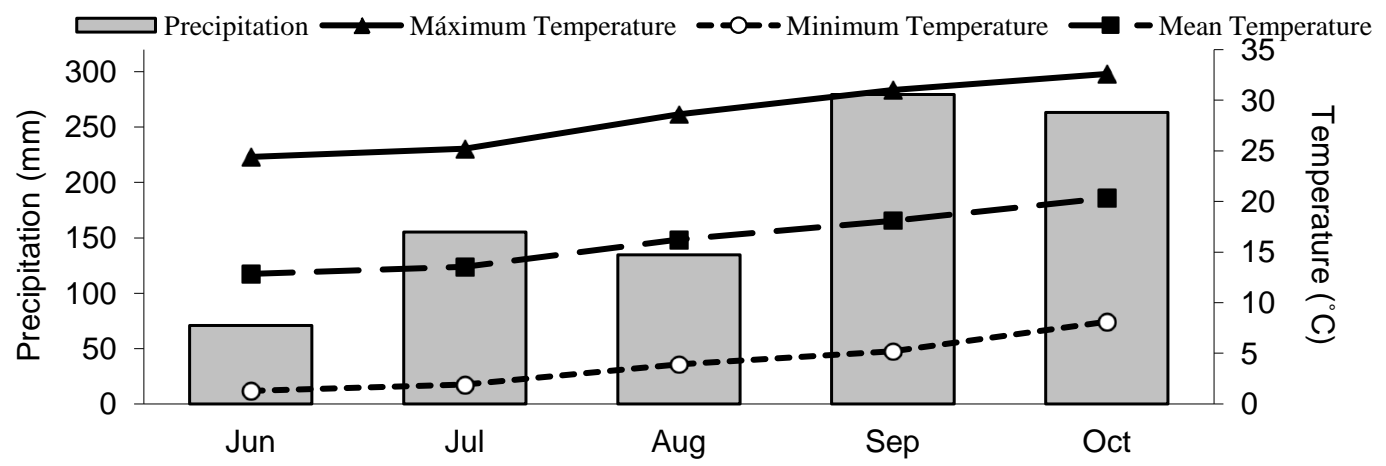

Figure 1. Data of precipitation and minimum temperature, maximum and average in the period from June to October of 2009 in the city of Pato Branco-PR. 
Basic fertilization was performed according to the results of soil analysis and recommendations used in the State of Paraná [19], being: $20 \mathrm{~kg} \cdot \mathrm{ha}^{-1} \mathrm{~N}, 60 \mathrm{~kg} \cdot \mathrm{ha}^{-1}$ of $\mathrm{P}_{2} \mathrm{O}_{5}$ and $60 \mathrm{~kg} \cdot \mathrm{ha}^{-1}$ of $\mathrm{K}_{2} \mathrm{O}$ using the formulated N (8)$\mathrm{P}_{2} \mathrm{O}_{5}(20)-\mathrm{K}_{2} \mathrm{O}(20)$.

The experimental design was complete randomized blocks, in factorial scheme $3 \times 5$ ( $\times \mathrm{N}$ doses genotypes), with three repetitions. Wheat genotypes were chosen: 108 CD (early cycle), CD 115 (middle cycle) and BRS 220 (middle cycle), and each genotype was subjected to doses of n: zero; 20; 40; 80 and $120 \mathrm{~kg}$ of $\mathrm{N} \cdot \mathrm{ha}^{-1}$, to check the growing effect of doses to the components of income, being applied at the beginning of tillering, using as source of $\mathrm{N}$ urea $(45 \% \mathrm{~N})$.

The harvest of the plants was performed manually after the beans have reached maturation (hence Stadium 11.4, Feekes scale). After harvesting were conducted the following reviews: number of Spike (NE), Tang (EC) length, grains per Spike (GE), mass of thousand grains (MMG), grain yield (R) with moisture corrected to 13\% and weight/HL (PH).

The results were submitted to analysis of variance, by f. when significant, averages were compared through Tukey test, at the level of $1 \%$ and $5 \%$ probability [19]. The $\mathrm{N}$ doses were evaluated by regression analysis. For determination of the degree of Association/dependency between variables was performed multivariate analysis and correlation of Pearson [20].

\section{Results and Discussion}

As variance analysis, the variables: NE, EC, GE, MMG, R and PH showed significant difference (Table 1). Thus, the $\mathrm{N}$ doses allowed different effects on variables responses, with emphasis to the NE and $\mathrm{R}$, as well as, also found different behavior of the cultivars compared the same variables. Significant interaction occurred, indicating that the factor cultivating and doses Act dependent on the NE, MMG and R (Table 1).

The nitrogen fertilization resulted in increases in the $\mathrm{NE}$ and $\mathrm{R}$ for the three genotypes evaluated (Figure 2(a) and Figure 2(b)). The highest dose provided increases of 53\%, $41 \%$ and $28 \%$ for the NE and $63 \%, 40 \%$ and $12 \%$ for R in cultivars, and BRS 220, CD 115 and CD 108 respectively, when compared to the dose $0 \mathrm{~kg}$ of $\mathrm{N} \cdot \mathrm{ha}^{-1}$. Both variables and genotypes behaved according to the nitrogen fertilization of quadratic form (Figure 2(a) and Figure 2(b)), not reaching the maximum technical efficiency level within the range of fertilizing adopts the corroborating with the results [21] that quadratic increases have to CE and R when subjected to nitrogen fertilization. Other R increases for wheat were also reported by Sobh et al. [22]; Saudy et al. [23] and Duan et al. [24].

The low yield in this culture is associated to high precipitation during the end of the cycle of culture (Figure 1) [25], observed in long-term studies that the excess of rain and decreased productivity of wheat and the efficiency of the use of $\mathrm{N}$ [26].

The variable MMG presented opposite behavior R, where, the BRS 220 and CD 115 cultivars showed higher values when not applied $\mathrm{N}$, corresponding to 12 and $11 \%$ in relation to the dose of $120 \mathrm{~kg}$ of N$\cdot \mathrm{ha}^{-1}$, respectively (Figure 3). This can be justified by the increase in NE provided by nitrogen fertilization, this variable which

Table 1. Summary of the analysis of the variables: number of Spike (NE), Tang (EC) length, grains per Spike (GE), weight of 1000 grains (MMG), income (R) and weight/HL (PH) of wheat cultivars in terms of doses of nitrogen (N).

\begin{tabular}{|c|c|c|c|c|c|c|c|}
\hline Fator variação & GL & $\mathrm{NE}$ & $\mathrm{CE}$ & GE & MMG & $\mathrm{R}$ & $\mathrm{PH}$ \\
\hline & & $\mathrm{m}^{2}$ & $\mathrm{~cm}$ & spikes $/ \mathrm{m}^{2}$ & G & $\mathrm{kg} \cdot \mathrm{ha}^{-1}$ & $\mathrm{~kg} \cdot \mathrm{hl}^{-1}$ \\
\hline Block & 2 & 440.03 & 0.45 & 8.63 & 10.65 & 7880.71 & 11.72 \\
\hline Cultivate & 2 & $2973.78^{* *}$ & $4.94^{* *}$ & $288.02^{* *}$ & $4.53^{\text {ns }}$ & $1127052.16^{* *}$ & $249.54^{* *}$ \\
\hline Doses N & 3 & $28833.2^{* *}$ & $0.29^{\text {ns }}$ & $2.92^{\mathrm{ns}}$ & $9.26^{*}$ & $721840.87^{* *}$ & $42.97^{\mathrm{ns}}$ \\
\hline Cultivate $^{*}$ Doses N & 6 & $1424.89^{*}$ & $0.06^{\mathrm{ns}}$ & $29.61^{\mathrm{ns}}$ & $8.94^{* *}$ & $65149.47^{* *}$ & $3.55^{\mathrm{ns}}$ \\
\hline Error & 22 & 468.36 & 0.29 & 14.27 & 2.22 & 12926.04 & 15.32 \\
\hline Total & 35 & & & & & & \\
\hline CV (\%) & & 5.81 & 7.35 & 10.86 & 4.57 & 5.27 & 5.41 \\
\hline
\end{tabular}

\footnotetext{
* * * and ns: significant to 1\%, 5\% not significant by Tukey test, respectively; GL: degrees of freedom; CV: coefficient of variation.
} 


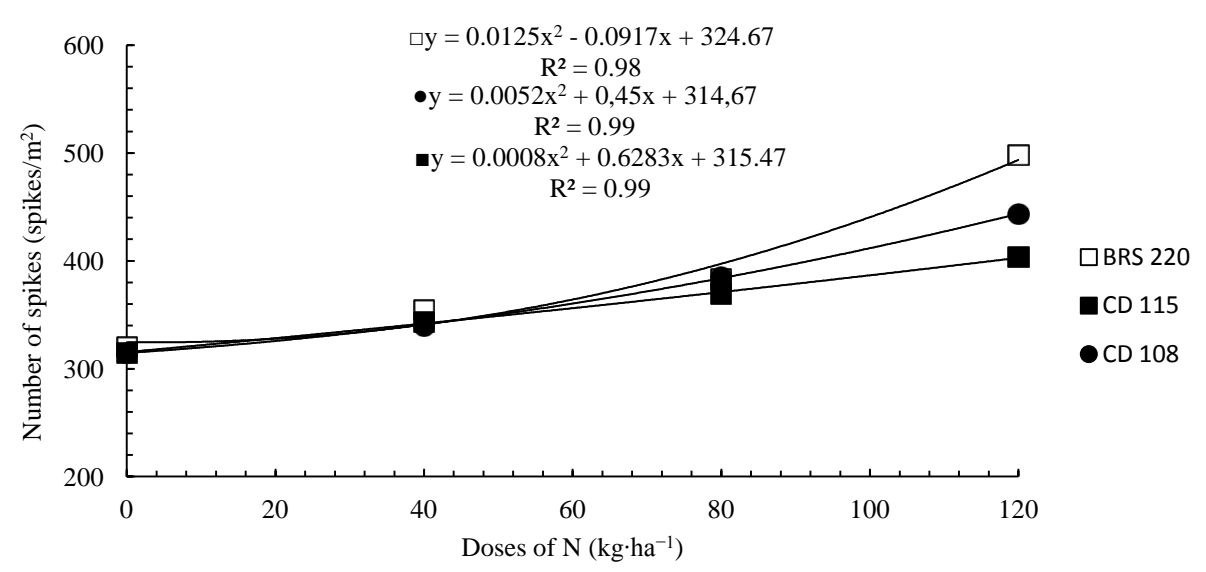

(a)

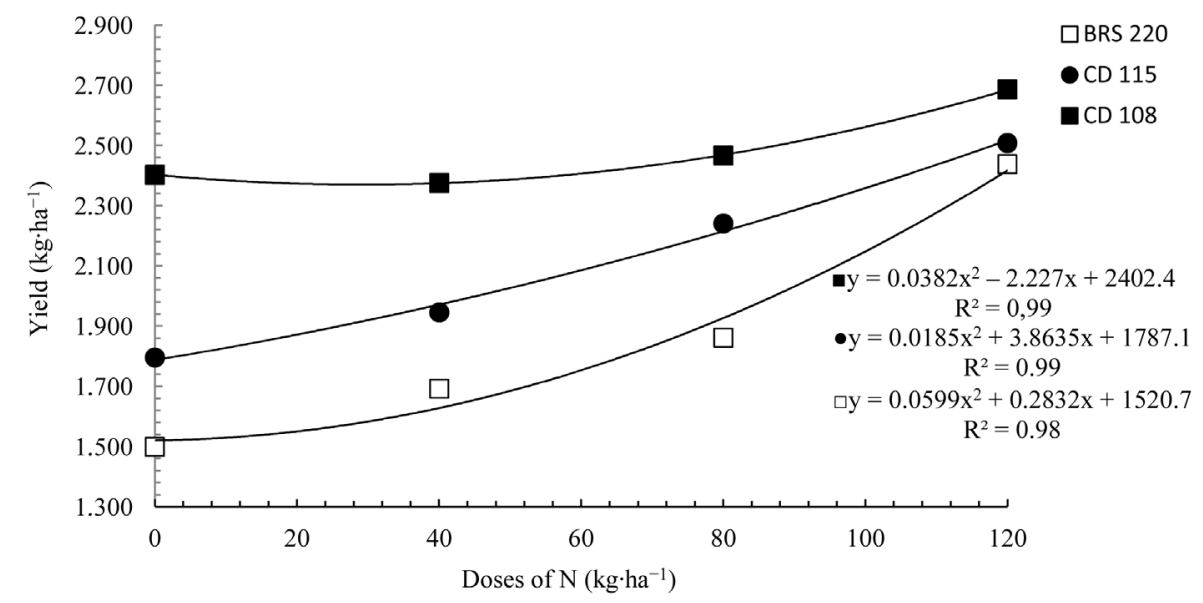

(b)

Figure 2. Number of Spike (NE) (a) and yield (R) (b) of wheat cultivars in terms of doses of nitrogen (N). ns and * not significant and meaningful to $5 \%$ respectively.

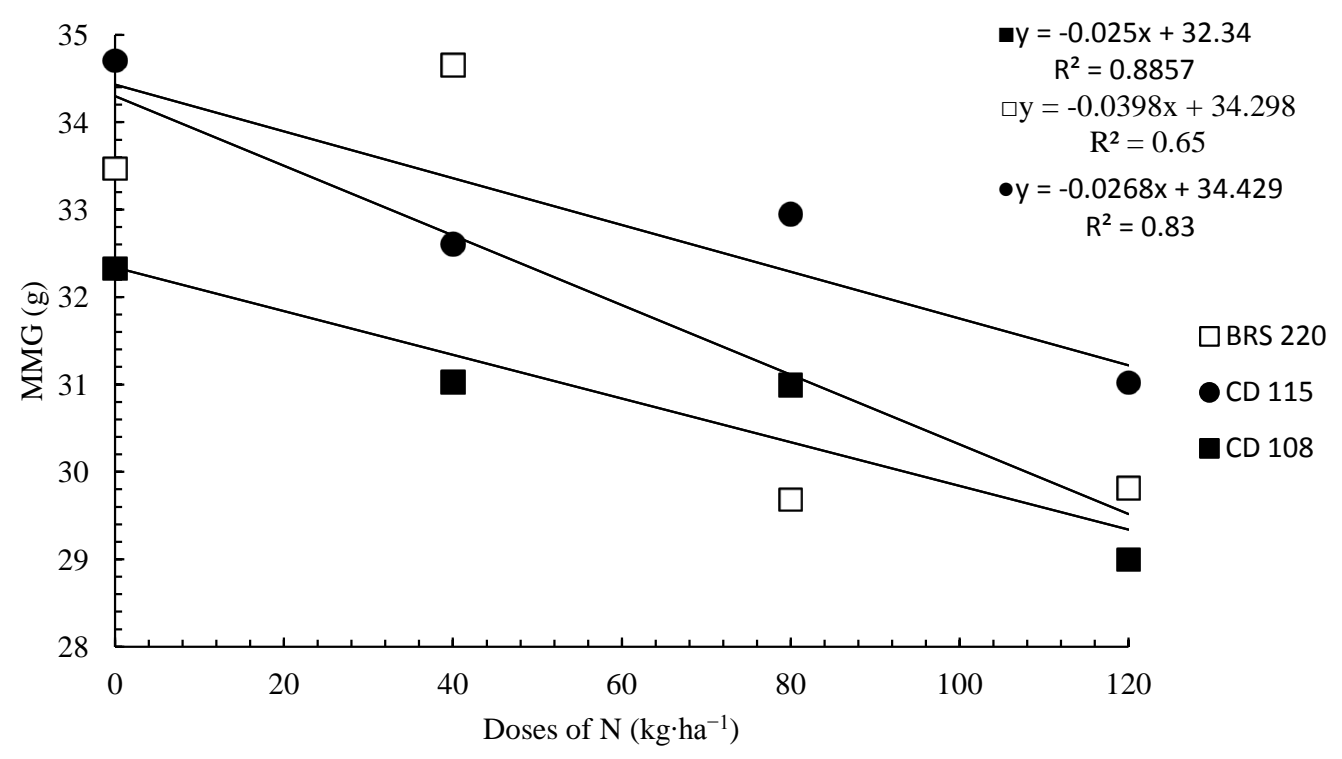

Figure 3. Weight of 1000 grains (MMG) of wheat cultivars in terms of doses of nitrogen (N). ns and ${ }^{*}$ not significant and meaningful to $5 \%$ respectively. 
is related directly with number of asons [27], in turn, the asons directly influence on physiological aspects of plants, as for example, the relationship source/drain. In this way, possibly larger partition occurred and/or fotoassimilados competition in plants of genotypes that presented the highest values of $\mathrm{NE}$, and consequently a lower filling grain. Similar results were obtained by Valerius et al. [28] when noted diminishing MMG on spike in wheat genotypes with greater number of asons. For MMG, the behavior was linear and decreasing with increasing dose of N, for the BRS 220 and CD 115 cultivars, and did not differ statistically to CD 108 (Figure 3).

For the other variables EC, GE and PH, there were no differences with regard to nitrogen fertilization. However, there was no difference between genotypes, in which, the cultivar BRS 220 stood out about GE, while the cultivar CD greater presented 115 CE and CD 108 the largest PH (Table 2). It is worth noting, too, that the cultivar BRS 220 presented greater NE (Figure 2(a)) and greater R 108 CD (Figure 2(b)). These behaviors are associated with genetic variation among genotypes, which also may influence the use and efficiency of response by $\mathrm{N}$ [29]. As Trinity et al. [30] the wheat yield components exhibit complex character, which are conditioned by several factors genetic and environmental origin, featuring variation between the answers of the genotypes. Add to that [31], report that environmental factors exert strong influence on response of wheat genotypes, with regard to aspects of income, in addition to the physiological.

To better understand the response of cultivars according to nitrogen fertilization was held principal component analysis (PCA), which explained the 63.6 set analyzed, with $33.2 \%$ of PC1 and PC2 30.4 percent (Figure 4). According to the results, the supply of $\mathrm{N}$, mainly at a dose of $120 \mathrm{~kg} \mathrm{of} \mathrm{N} \cdot \mathrm{ha}^{-1}$, provides the best indexes of $\mathrm{R}$ in all genotypes studied. It should be noted that the $\mathrm{R}$ is related directly with $\mathrm{NE}$, i.e. According to the results of this study to the NE is the main factor that affects the R with N supply. The example has the cultivar BRS 220, which although present smaller $\mathrm{R}$ among the cultivars evaluated, exhibited greater $\mathrm{NE}$ with $\mathrm{N}$ supply (53\% increase in dose $120 \mathrm{~kg}$ of $\mathrm{N} \cdot \mathrm{ha}^{-1}$ ) and consequently greater $\mathrm{R}$ increases ( $63 \%$ at $120 \mathrm{~kg}$ of $\mathrm{N} \cdot \mathrm{ha}^{-1}$ ). The remaining variables evaluated do not exhibit any behavior so predominant in relation to the provision of the $\mathrm{N}$ doses.

The PCA showed strong relationships between the doses of $\mathrm{N}$, genotypes and variable responses. These relationships were quantified and characterized also by the Pearson correlation, where it was possible to check for the genotype, positive correlations between 220 BRS: Doses $\mathrm{N} \times \mathrm{NE}(0.91)$, Doses $\mathrm{N} \times \mathrm{R}(0.91)$ and $\mathrm{NE} \times \mathrm{R}$ (0.92) and negative correlation between: $\mathrm{N} \times$ Doses MMG. For genotype positive correlations between $\mathrm{CD}, 115$ : Doses $\mathrm{N} \times \mathrm{NE}(0.91)$, Doses $\mathrm{N} \times \mathrm{R}(0.96)$ and $\mathrm{NE} \times \mathrm{R}(0.87)$ and negative correlation between: $\mathrm{N} \times$ Doses MMG ( -0.64$)$ to the positive correlations between CD108 genotype: Doses $\mathrm{N} \times \mathrm{NE}(0.92)$, Doses $\mathrm{N} \times \mathrm{R}(0.72)$ and $\mathrm{NE} \times \mathrm{R}(0.67)$. However, it is observed in General, genotypes responded similarly about doses of $\mathrm{N}$ to NE, MMG and R. It is noteworthy, too, that this information demonstrates the importance of a correct fertilization of $\mathrm{N}$ on wheat culture, because when applied, whether in low or high amounts, directly affects productivity.

\section{Conclusion}

Fertilization with $\mathrm{N}$ provided increases to the NE and the R and decreased the MMG in wheat genotypes. The increase for NE and R was growing, while quadratic for MMG was linear and descending with the bidding No. genotypes differed among themselves; the BRS 220 presented greater NE and GE, the largest EC CD 115 and the CD 108 largest R and PH. There were positive correlations between the doses of $\mathrm{N}$ with the $\mathrm{NE}$ and $\mathrm{R}$ and between $\mathrm{NE}$ with the R, and negative correlation between doses of $\mathrm{N}$ with the MMG. However, it is possible to affirm that the NE is the main factor that affects the $\mathrm{R}$ with $\mathrm{N}$ supply and nitrogen fertilization should be weighted, as there is yield components behavior inversely proportional to N-tier application.

Table 2. Spike length (EC), grains per Spike (GE) and weight/HL (PH) wheat varieties in relation to the doses of nitrogen.

\begin{tabular}{cccc}
\hline Grow & CE $(\mathrm{cm})$ & GE $\left(\right.$ espigas $\left./ \mathrm{m}^{2}\right)$ & $\mathrm{PH}\left(\mathrm{kg} \cdot \mathrm{hl}^{-1}\right)$ \\
\hline BRS 220 & $7.2 \mathrm{ab}^{(1)}$ & $38.3 \mathrm{a}$ & $74.2 \mathrm{ab}$ \\
CD 115 & $7.9 \mathrm{a}$ & $36.8 \mathrm{ab}$ & $67.0 \mathrm{~b}$ \\
CD 108 & $6.7 \mathrm{~b}$ & $29.2 \mathrm{~b}$ & $75.5 \mathrm{a}$ \\
Media & 7.2 & 34.7 & 75.2 \\
\hline
\end{tabular}

\footnotetext{
${ }^{(1)}$ Medium followed by the same letter does not differ statistically by Tukey test at 5\% probability.
} 


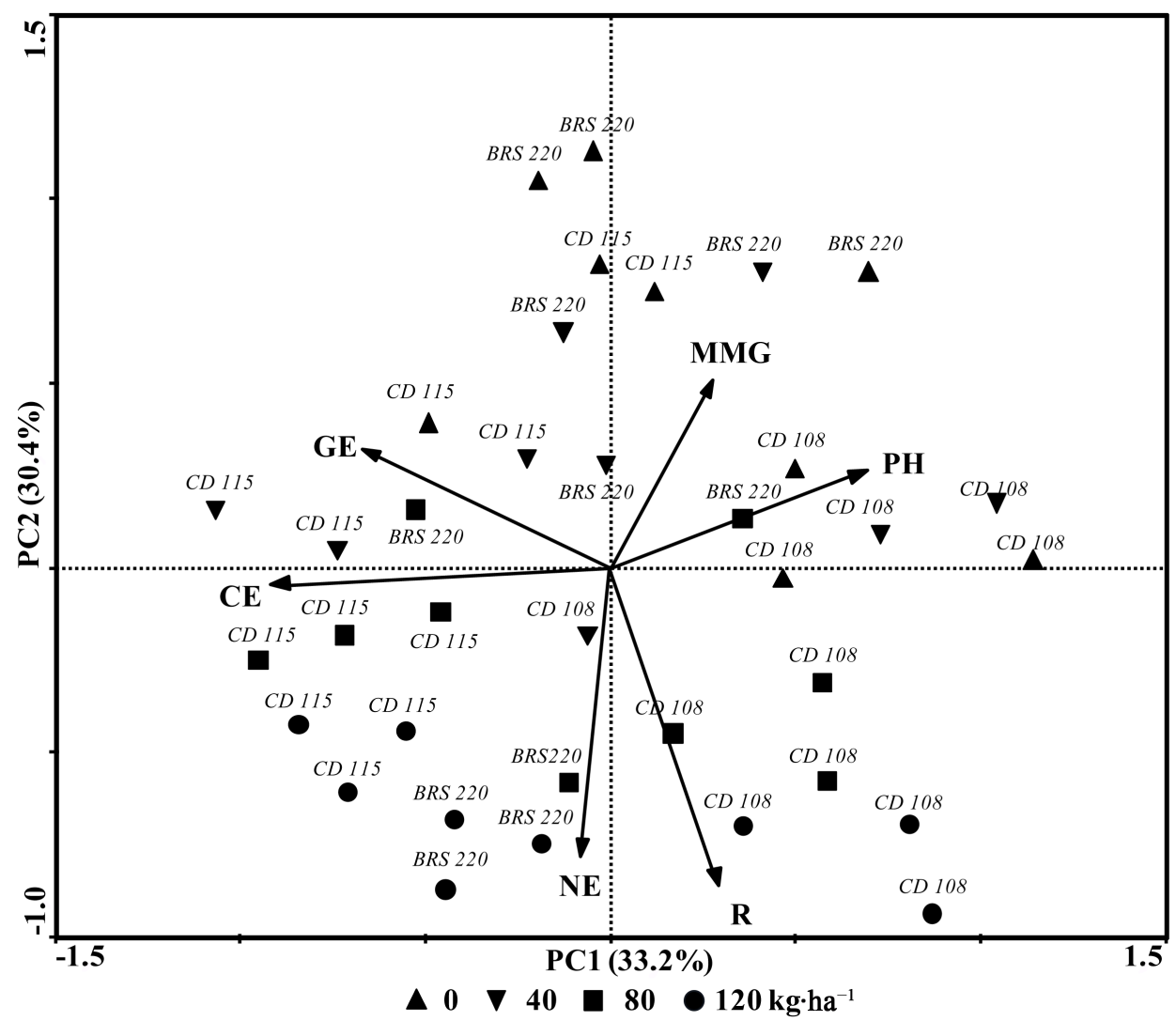

Figure 4. Principal component analysis (PCA) of wheat cultivars BRS 220, 115 CD and CD 108 according to doses of nitrogen $(\mathrm{N})\left(0,40,80\right.$ and $\left.120 \mathrm{~kg} \cdot \mathrm{ha}^{-1}\right)$ (MMG: mass of 1000 grains, PH: weight/HL, R: income, NE: number of spikes, EC: length of spikes, GE: number of grains per spike).

\section{Acknowledgements}

Thank God, to contemplate us with great wisdom and ability, great is our Lord that keeps us and always has the best for our lives, just trust in faith that he will do more. To our families by encouraging and comprehension. The team for the friendship and companionship, especially the researcher Wilson Wagner Ribeiro Teixeira.

\section{References}

[1] FAO—Food and Agriculture Organization of the United Nations (FAOSTAT) (2014). http://faostat.fao.org/site/567/default.aspx\#ancor

[2] Ministry of Agriculture and Supply (SEAB) (2014) Agricultural Production. www.agricultura.pr.gov.br/modules/conteudo/conteudo.php?conteudo=137

[3] Koehler, P., Hartmann, G., Wieser, P. and Rychlik, M. (2007) Changes of Folates, Dietary Fiber, and Proteins in Wheat as Affected by Germination. Journal Agricultural and Food Chemistry, 55, 4678-4683. http://dx.doi.org/10.1021/jf0633037

[4] Graham, R.D., Welch, R.M. and Bouis, H.E. (2001) Addressing Micronutrient Malnutrition through Enhancing the Nutritional Quality of Staple Foods: Principles, Perspectives and Knowledge Gaps. Advances in Agronomy, 70, 77142. http://dx.doi.org/10.1016/s0065-2113(01)70004-1

[5] Scott, D.B. and Goto, W.S. (1991) Dryland Wheat Response to Nitrogen, after Early Soy, in the Region of the Alto Paranaiba, MG. Brazilian Agricultural Research, 26, 1.405-1.401.

[6] Ehdaie, B. and Waines, J.C. (2001) Sowing Date and Nitrogen Rate Effects on Dry Matter and Nitrogen Partitioning in Bread and Durum Wheat. Field Crops Research, 73, 47-61. http://dx.doi.org/10.1016/s0065-2113(01)70004-1

[7] Acorssi, E.E. and Ferreira, D.T.L. (2009) Productive Response of Wheat Culture on Cultivating CD 104 Subjected to Different Doses of Nitrogen Fertilizer Applied in Coverage. Cultivating Knowledge, Cascavel, 2, 165-173. 
[8] Rongli, S.H.I., Zhang, Y.Q., Chen, X.P., Sun, Q.P., Zhang, F.S., Romheldd, V. and Zou, C. (2010) Influence of Long-Term Nitrogen Fertilization on Micronutrient Density in Grain of Winter Wheat (Triticum aestivum L.). Journal of Cereal Science, 51, 165-170. http://dx.doi.org/10.1016/j.jcs.2009.11.008

[9] Barraclough, P.B., Howarth, J.R., Jones, J., Lee Bellido, A., Parmar, S., Shepherd, C.E. and Hawkesford, M.J. (2010) Nitrogen Efficiency of Wheat: Genotypic and Environmental Variation and Prospects for Improvement. European Journal of Agronomy, 33, 1-11. http://dx.doi.org/10.1016/j.eja.2010.01.005

[10] Teixeira Filho, M.C.M., Buzetti, S., Andreotti, M., Arf, O. and Benett, C.G.S. (2010) Sources, Doses and Times of Nitrogen Application in Wheat in Irrigated Tillage. Research. Brazilian Agriculture, 45, 797-804.

[11] Mielniczuk, J. (1982) Nitrogen Fertilization. In: Wheat in Brazil, Foundation Cargill, Campinas, 294-301.

[12] Scott, D.B. (1992) Effect of Boron and Nitrogen in Irrigated Wheat Yield and the Nutrient Content in the Plant, in the Region of the Cerrado. Brazilian Agricultural Research, 27, 1557-1562.

[13] Freitas, J.C., Camargo, C.E.O., Flowers, A.W.P. and Castro, J.L. (1995) Efficiency and Response of Wheat Genotypes to Nitrogen. Journal of Soil Science, 19, 229-234.

[14] Vieira, R.D., Fornasieri Son, D., Minohara, L. and Bergamaschi, M.C.M. (1995) Effects of Doses and Times of Nitrogen Application in Production and Wheat Seed Physiological Quality Coverage. Science, 23, 257-264.

[15] Garnett, T., Conn, V. and Kaiser, B.N. (2009) Root Based Approaches to Improving Nitrogen Use Efficiency in Plants. Plant, Cell \& Environment, 32, 1272-1283. http://dx.doi.org/10.1111/j.1365-3040.2009.02011.x

[16] Maack, R. (1968) Physical Geography of the State of Paraná. The Development Bank of the Paraná. UFPR/IBPT, Curitiba, 350 p.

[17] EMBRAPA (2013) Brazilian System of soil Classification. 3rd Edition, Embrapa Solos, Rio de Janeiro, 353 p.

[18] Brazilian Committee Meeting of Wheat Research (2008) Technical Information for the 2009 Crop: Wheat and Triticale. Embrapa Wheat, Passo Fundo, 172 p.

[19] Commission of Chemistry and Soil Fertility (CQFS RS/SC) (2004) Manual of Fertilizing and Liming for the States of Rio Grande do Southl and Santa Catarina. 10th Edition, Brazilian Society for Soil Science, London, 400 p.

[20] Pimentel-Garcia, F. and Garcia, C.H. (2002) Applied Statistics the Agronomic and Forestry Experiments: Exhibition with Examples and Guidelines for Use by Applications. FEALQ, Piracicaba, 309 p.

[21] Teixeira Filho, M.C.M., Buzetti, S., Alvarez, R.C.F., Freitas, J.G., Arf, O. and Samuel, M.E. (2007) Reply Cultivars of Wheat Irrigated by Sprinkling the Nitrogen in Coverage in the Region of the Cerrado. ACTA Scientiarum-Agronomy, 29, 421-425.

[22] Sobh, M.M., Sharshar, M.S. and El-Said, A.S. (2000) Response of Wheat Plants to Nitrogen and Potassium Application in Salt Affected Soil. Journal Product, 5, 83-97.

[23] Saudy, H.S., El-Habbal, M.S., Ashmawy, F., Soliman, E.M. and Abbas, I.K. (2008) Using Chlorophyll Meter for Predicting Wheat Nitrogen Requirements. Annals of Agricultural Science, 46, 299-308.

[24] Duan, Y., Xu, M., Gao, N., Yang, X., Huang, S., Liu, H. and Wang, B. (2014) Nitrogen Use Efficiency in Wheat-Corn Cropping System from 15 Years of Manure and Fertilizer Applications. Field Crops Research, 157, 47-56. http://dx.doi.org/10.1016/j.fcr.2013.12.012

[25] López-Bellido, R.J., López-Bellido, L., Castillo, J.E. and López-Bellido, F.J. (2004) Chickpea Response to Tillage and Soil Residual Nitrogen in a Continuous Rotation with Wheat: II Soil Nitrate, N Uptake and Influence on Wheat Yield. Field Crops Research, 88, 201-210. http://dx.doi.org/10.1016/j.fcr.2004.01.012

[26] López-Bellido, R.J. and López-Bellido, L. (2001) Efficiency of Nitrogen in Wheat under Mediterranean Conditions: Effect of Tillage, Crop Rotation and N Fertilization. Field Crops Research, 71, 31-46. http://dx.doi.org/10.1016/S0378-4290(01)00146-0

[27] Davidson, D.J. and Chevalier, P.M. (1990) Parenthesis Tiller Mortality in Spring Wheat. Crop Science, 30, $832-836$. http://dx.doi.org/10.2135/cropsci1990.0011183X003000040013x

[28] Valerius, I.P., Carvalho, F.I.F., Oliveira, B.C., Machado, A.A., Benin, G., Scheeren, P.L., Souza, V.Q. and Hartwig, I. (2008) Development of Asons and Income Components in Wheat Genotypes under Different Sowing Densities. Brazilian Agricultural Research, 43, 319-326.

[29] Ortiz-Monasterio, R., Sayre, K.D., Rajaram, S. and Mcmahon, M. (1997) Genetic Progress in Wheat Yield and Nitrogen Use Efficiency under Four N Rates. Crop Science, 37, 898-904. http://dx.doi.org/10.2135/cropsci1997.0011183X003700030033x

[30] Trinity, M.G., Stone, L.F., Heinemann, A.B., Abelardo, D.C. and Moreira, J.A.A. (2006) Nitrogen and Water the Factors of Productivity of Wheat in the Cerrado. Journal of Agricultural and Environmental Engineering, 10, 24-29.

[31] Gao, X., Lukow, O.M. and Grant, C.A. (2012) Grain Concentrations of Protein, Iron and Zinc and Bread Making Quality in Spring Wheat as Affected by Seeding Date and Nitrogen Fertilizer Management. Journal of Geochemical Exploration, 121, 36-44. http://dx.doi.org/10.1016/j.gexplo.2012.02.005 